\title{
Development of Motor Teaching Learning Models Based on Audio Visual Media for Elementary School Students in Kuranji Padang
}

\author{
F Haris $^{1 *}$, F Mukhtarsyaf ${ }^{1}$, Liza $^{1}$ \\ ${ }^{I}$ Faculty of Sport Science, Universitas Negeri Padang, Prof. dr.Hamka, Padang, Indonesia \\ "Corresponding author. Email: fahmilharis@fik.unp.ac.id, fahdm6231@fik.unp.ac.id
}

\begin{abstract}
The problem when the author made observations and interviews with the Teachers in Elementary School in Kuranji Subdistrict, Padang was the rarely conducted evaluation of Learning Physical education and motor skills of students, especially motor skills of Elementary School Students in Kuranji District, Padang. This causes the development of Motion cannot be monitored regularly. The development of motorized motor technology is less noticed. To respond to this problem, the authors are interested in making motor skills learning media from elementary school students in Kuranji sub-district, Padang. the target to be achieved from this research is to make the development of the Penjas learning model using audio visual media in SDN Kuranji sub-district Padang to provide solutions to the existing problems. This research uses Borg and Gall research and development research development methods. The output of this research is a product in the form of Video CD (compact disk) and teaching materials books on motor learning model based on audio visual media through playing post play in SDN Kuranji Subdistrict, Padang city. The results of this study conclude the development of the model of motor learning Primary school students through the Pos play approach based on audio visual media according to motor learning experts and media experts are considered effective and well used for elementary students elementary motor learning and get good responses from elementary school students in Kuranji District Padang.
\end{abstract}

Keywords: Motor teaching learning models, audio visual media, elementary school students

\section{INTRODUCTION}

Physical education is one of the compulsory subjects at each level of formal education units in Indonesia in accordance with the Law of the Republic of Indonesia No. 20 of 2003 concerning the National Education System article 37 paragraph 1: Physical education and sports are basically an integral part of the education system as a whole which aiming to develop aspects of health, physical fitness, critical thinking skills, emotional stability, social skills, reasoning, and actions moral through physical activity and sports. Physical education and sports become a medium to encourage the development of motor skills, physical abilities, knowledge, reasoning, appreciation of values (attitude, mental, emotional, spiritual, and social), and habituation to healthy lifestyles that lead to stimulate balanced growth and development.

Growth and development are found in the field, teachers seem to have difficulties in achieving their learning goals. Learning material that has been programmed is often delayed or cannot be completed according to the limited and short meeting time, so as a result motoric teaching and learning processes in the subject matter become ineffective. For this reason, it is necessary to develop a model of motor learning that is more appropriate, complete and fun for students. Packaging of learning material is made in the form of a model adapted to the characteristics of students who are faced, namely elementary school students.

Motor learning is learning through physical activity which involves large muscles and small muscles in motion. Motor learning aims to increase the physical potential of children so that they can be useful for children's daily activities. The process of motor learning can be done through physical activities such as running, skipping, and jumping. Gross motor learning is very important to be taught early because motor learning has many benefits including stimulating the proper functioning of the body and stimulating all organs of the body to develop.

The process of motor learning for elementary school students can be done in various ways. One of the effective ways is by playing a post play. Post play is the 
activity most liked by children because children will feel relaxed and not burdened by playing. This is reinforced by the opinion of Tedjasaputra (2001) who stated that playing is a fun activity and an inherent need for children. Play activities that are conceptualized as elementary school students' motorbike learning strategies should not be arbitrarily done.

Selection of the right media is very instrumental in improving learning outcomes. The type of media used must be in accordance with the learning plan that will be taught. According to Asyhar (2012) "although various types and formats of media have been developed and used in learning, basically all of these media can be grouped into four types, namely visual media, audio media, audia-visual media and multimedia."

Learning media that can be used by students to learn independently is CD (compact disk) learning. Visual media is a medium that can only be seen, such as media images, photos, posters and others. Audio media is a medium that can only be heard like a radio while audiovisual media is a medium that can be seen and heard like movies and videos. In addition, there is multimedia which is a medium that involves several types of media and equipment in an integrated manner in a learning process. The existence of learning media like this is expected to be able to help students to learn independently and also increase students' understanding of the material presented in it. For media teachers this can be used as a form of development in learning media in the form of teaching materials that can help facilitate the delivery of learning material to the students.

This type of motor learning in the form of media that is intended for elementary school students must be in accordance with the child's ability, provide education, and stimulate children's development according to the physical stages. Giving play activities that are not in accordance with the child's ability will have a negative impact on the child's development both physically and mentally.

Based on observations which was made by researcher in the elementary school of Kuranji subdistrict, Padang, he was illustrated that there were several problems in the process of motor learning, the lack of teacher creativity that causes the students could not master motor skills, and also the problems of rigidity and disability in moving to the sport which developed into not met the needs of students would move later on.

In my opinion, the researcher remembers the importance of the material of motor learning and basic movements of children in relation to media, so it is necessary to develop a media that can accommodate the needs of students who are able to improve their understanding and motivation in learning. Any further research is needed these problems so that they does not make a chronic disease that makes it worse for individual students and the future progress of the nation.

Facing this phenomenon, the researchers are interested in providing solutions in the form of developing motorized learning models through play post, so on this occasion the researcher reveal in a research title entitled: "Development of Motor Learning Model Based on Visual Audio Media for Elementary Students in Kuranji Subdistrict, Padang ".

\section{METHOD}

The type of this research was a research and development model according to Gall, M. D., Borg, W. R., \& Gall, J. P. (1996) namely (Research \& Development). This research was carried out in Elementary School Students in Kuranji Subdistrict, Padang City. This research was carried out in July and September 2018. The population of this study were all elementary school students in the District of Padang City. Samples were taken by random sampling. This research instrument used the test of the effectiveness of the motor ability of elementary school students using the play post system which was presented in the form of a video that was validated by motor learning experts and media experts.

\section{RESULT AND DISCUSSION}

\section{Analysis Requirements Test}

This study was tested using an analyst from the initial draft of the validated elementary students' basic motor learning model. In this research, a small-scale trial was conducted at elementary school number 10 of Balai Baru with 10 students taught by two teachers. From the implementation of small-scale trials, the researcher obtained three data, namely (1) observational data of elementary school students 'motor learning model, (2) observational data on the effectiveness of elementary students' motor movement learning model, (3) input data on elementary student learning motion model.

Small-scale trial data were obtained from 16 questions submitted to expert. In the question item, there are four different rating scales. The data obtained was then processed using a Likert scale so that an assessment of the model is carried out. The following was presented validation data and frequency distribution of conformity assessment by expert in small-scale trials of motor skills learning models of elementary school students.

\section{Research Analysis Phase}

The first stage carried out by researcher was the analysis phase of research. At this stage, the researcher 
conducted a needs analysis. Needs analysis was carried out through interviews and direct observation.

\section{Observation}

Observation is a technique or method of collecting data by conducting observations of ongoing activities. Observation is the initial activity in media development procedures. This observation is to identify the needs in media development. Interviews were conducted on Physical Education, Sports teachers at elementary school number 10 of Balai Baru, Kuranji subdistrict, Padang.

\section{Interview}

Interviews are used as a data collection technique if the researcher wanted to conduct a preliminary research to find problems that must be examined, and also if the researcher wanted to know the respondents' matters more deeply and the number of respondents was a little or small. Interviews were carried out during the physical education learning process. done on July 2, 2018.

\section{Product Planning and Design}

Product planning and design was the second stage of research. At this stage, researcher plan the product and design that had been adapted to the needs of students who were known through the results of the research analysis. It got through expert validation and product testing.

\section{Initial Product Development}

The initial product development was in the third place of research. This stage was the stage of translating product design and design specifications into physical form, namely audio visual media.

Data from the evaluation of motorized learning model products based on audio visual media by the second stage media expert showed that the results of product evaluation from the coloring quality aspects, the use of words and languages, screen display, presentation, animation and sound got the following scores:

The score results were then converted into formulas (Arikunto:2008). Based on the results of the data analysis above, the results of the evaluation of the learning material expert (Dr. Anton komaini, S.Si., M.Pd) on the product of motor skills learning model based on audio visual media was $93.33 \%$ with information worthy to be used in the next motoric learning for elementary school students in Kuranji subdistrict, Padang. It meant that this product was worth testing.
The results of the evaluation of Learning media experts (Dr. Abna hidayati, M.Pd) on the product of motor skills learning model based on audio visual media is $96 \%$ with with information worthy to be used in the next motoric learning of elementary school students in Kuranji subdistrict, Padang. It meant that this product was worth testing.

Based on expert validation and tested in small groups, the results of expert evaluation of learning (Syahrul, S.Pd) on the product of motor skills learning model based on audio visual media was $94.66 \%$ with information worthy to be used in the next motoric learning of elementary school students in the subdistrict Kuranji, Padang. It meant this product was worth testing.

Initial Field Test; This field test was carried out in small groups. The small group in question includes 4 students (respondents) of the fifth grade students at elementary school number 10 of Balai Baru, Kuranji subdistrict, Padang. Small group trials involved several student samples which were taken based on students' level of understanding of the material or learning outcomes achieved through value data from the physical education teacher. An evaluation of product implementation in small group was carried out during this initial trial phase. Evaluation was done by distributing respondents' validation questionnaires after conducting product trials. Instruments for respondents.

Product Revision; The product revision phase carried out the product implementation stage in the initial field trial (small group), the researcher conducted the product revision stage. Product revision was carried out based on the results of product implementation evaluation on the small group questionnaire.

Major Field Test; This field test was carried out in large group. The large group included 20 students (respondents) of the fifth grade students at elementary school number 10 of Balai Baru, Kuranji subdistrict, Padang. At this stage, there was also an evaluation carried out by distributing the respondent validation questionnaire (students) after testing the product.

Final Product Revision; The final stage in the research was the final revision. After carrying out the product implementation phase in the major field trial (large group), the researcher conducted the product revision stage. Product revisions were carried out based on the results of evaluating the product implementation in the main group. After the average value of each validator was known, then the next step was to calculate the total average by summing the average value of all validators and dividing by the number of validators. 
Based on data analysis, the average of each validator was: $(93.33 \%+96 \%+94.66 \%): 3=94.66 \%$.

The results obtained based on calculations performed with the formula above were used to determine the validity of learning media based on audio visual media. The validity of audio visual media was determined based on intervals, determining the level of validity in the table below (Arikunto: 2008).

Table 1. Validity level of audio visual media.

\begin{tabular}{|c|c|c|}
\hline $\begin{array}{l}\text { The amount of } x \\
\text { (Average) }\end{array}$ & Category & Description \\
\hline $\begin{array}{l}80 \%<x<100 \% \\
66 \%<x<84 \% \\
56 \%<x<66 \% \\
40 \%<x<56 \% \\
0 \%<x<40 \%\end{array}$ & $\begin{array}{l}\text { Valid } \\
\text { Quite valid } \\
\text { Less valid } \\
\text { Invalid } \\
\text { Invalid }\end{array}$ & $\begin{array}{l}\text { Valid } \\
\text { Valid } \\
\text { Replaced } \\
\text { Replaced } \\
\text { Replaced }\end{array}$ \\
\hline
\end{tabular}

Based on the results of validation by material experts and media experts on products based on motoric learning models audio visual media in elementary schools in Kuranji subdistrict, Padang, included in the valid category $(94.66 \%)$ which means that the model is feasible/worthy to be tested.

\section{CONCLUSION}

Product conclusions are the core of the product. There are several conclusions in the research on the development of motoric learning model of elementary school students. The following are the conclusions of the development of elementary students' basic movements: Development of motoric learning models of elementary school students through the post-themed play approach with research and development methods resulting in games namely 1) running to catch kites, 2) balance of airplanes, 3) jumping horses 4) walking like parrot, 5) throwing dinosaur's eggs. Development of motor skills learning model with audio visual media based on play approach, playing, is worthy to be used to motoric learning in elementary school students in Kuranji subdistrict, Padang.

\section{REFERENCES}

[1] Aberle, E. D, J. C. Forrest, D. E. Gerrard, and E.W. Mills. 2001. Principles of Meat Science. 4th ed. Hunt Publishing Company, Kendall.

[2] Arief S Sadiman, et al. 2006. Media Education. Jakarta: PT Raja Grafindo. Persada. Max Darsono et al. 2001. Learning and Learning. Semarang: IKIP Press.
[3] Asyhar, Rayanda. 2012. Creative Developing Learning Media. Jakarta: Gaung Persada (GP) Jakarta Press.

[4] Azhar. 2010. Learning Media. Jakarta: PT Raja Grafindo Persada.

[5] Breckenridge JD and McAuley JH (2011). Shoulder pain and disability index (SPADI). Journal of Physiotherapy: Australian Physiotherapy Association; 57: 197.

[6] Kusyanto. 1999. Guidelines for Physical Education and Health Learning I, (Based on New Curriculum 6 BPP 1994). Bandung: Ganesa Axact Bandung.

[7] Corbin, C. B. (1980). A textbook of motor development. Wm C. Brown Company Publishers: Gowa.

[8] Gall, M. D., Borg, W. R., \& Gall, J. P. (1996). Educational research: An introduction. Longman Publishing.

[9] Mansur. 2005. Early Childhood Education in Islam, 2005, Yogyakarta: Student Literature.

[10] Sagala, Syaiful. 2012. Concepts and Meanings of Learning, Bandung: Alfabeta.

[11] Sujiono, Yuliani Nurani. 2009. Basic Concept of Early Childhood Education. Jakarta. PT Index

[12] Sudjana, Nana. and Ibrahim 2007, Educational Research and Assessment, Bandung: Sinar Baru Algensindo,

[13] Sugiyono. 2013. Easy Ways to Compile: Thesis, Thesis and Dissertation. Yogyakarta: ALFABETA,

[14] Sugiyono. 2011. Qualitative quantitative research methods and R \& D. Bandung: Alfabeta,

[15] Syarifudin, Aip and Muhadi. 1992/1993. Physical education and Health Sciences. Jakarta: Ministry of Education and Culture,

[16] Tedja Saputra, 2001, Playing, Toys and Games, Jakarta, PT. 